\title{
THE STRUGGLE OF THE MAIN CHARACTER IN THE MOVIE DJANGO UNCHAINED BY QUENTIN TARANTINO
}

\author{
Istiwarni Diah \\ STIBA-IEC Jakarta \\ Latifah Nuraini \\ STIBA-IEC Jakarta
}

\begin{abstract}
The purpose of this research is to find out how struggle of the main character against injustice from the white people around them. The research is conducted by using qualitative method; the writer uses two data sources, namely primary and secondary data source. The primary data is movie Django Unchained directed by Quentin Tarantino. The secondary data sources are the other sources related to this thesis like books about the movie. There are three objectives of this study. First, the kind of struggle of the main character as a slave that shows in movie. Second, factors that influenced black people become slave in movie. It makes black people get pressure from white people. Third the way slave can survive in pressure of white people. The results of the research are as follows; in the end, it can be concluded that the struggle for freedom can find happiness. Finally, Django as a main character and other slaves get their struggle for freedom after overcoming against their master.
\end{abstract}

Keywords: Character, struggle, racism, slave.

\section{A. INTRODUCTION}

\section{Background}

Everyone has human right from their born until died. The right is not only for living, but also for freedom. What is human right? According to Equality and Human Rights Commission human rights are the rights that belong to every person in the world, from birth until death. People cannot do discriminations, whatever our nationality, place of residence, sex, national, ethnic origin, colour, religion, language, or any other status. All human beings are born free and equal in dignity and rights.

Many cases of violation human rights that happen in this world, for example; slavery, human trafficking, prostitution, discrimination and torture: slavery 
is one of violations human right and still often occurs even in modern era. It is the situation that authorized by power. There is one of example of the slavery in modern era. According to news from Kompas.com, 01 August 2013 in Tangerang, Banten.There are 34 labours work compulsively to make 200 pans more than 12 hours in a day without eating, and resting. If they cannot reach the target, they will get punishment and torture.

From the case above can be concluded that there are slaves and master.According to Dorito slave is someone who is owned by another person, a slave does not have choice, freedom, and money.In other example slavery cases arefound in The United State, because there are many people come to there with a different purpose.They are blacks who caught from Africa to be sold as slave there was no choice for them.For more than three hundred years during African enslavement was practiced, African descendants became subjects to discrimination.

White American treated black people inhumanely, this circumstance forced Black people to fight against their condition of being discriminated of the equal rights in all aspects in their lives. In the racism's case the writer sees struggle of slave who get violence and torture from their master. They have to survive in worst condition without any help. Struggle needed to defend in our live.

Based on the case above the writer tries to analyze struggle of the main character. In this movie describes how does the main character against injustice that he gets from White people around him, and wants to get right for livingand freedom as human not a slave.From this movie also shows The Black people do struggle hard to be able defend their live from the White people. It will discuss in next chapter.

\section{Objectives}

The writer uses some objectives of study can be stated as follows : (1) to know the struggle through the main character reflected in the movie; (2) To find the factors that influence the white people to the black people; and (3) to know the black people survive in the movie. 


\section{Theoretical Framework}

\subsection{Definition of Character}

The character is the part of intrinsic element in the movie that is firstly explored by the writer because it takes essential role to display any behaviour of each character in the movie. The moment a character is introduced carries the ability to show some of the most powerful emotions in the world.

David Rush (2005:46) said that characters in plays, like people in real life, are usually driven by one or more primary desires. They, like us, want to be happy, or safe, or successful, or loved. These, however, are inner goals. They are private, they live in the heart, mind, or soul of a character.

Meanwhile, according to Lukens (2007:76), the definition of character, as the term is generally used, means the aggregate of mental, emotional, and social qualities that distinguish a person. In literature however, the term character is used to mean a person, or in the case of children's literature, sometimes a personified animal or object. Each of living beings in a story, play, or poem is a character.

According to Meyer (1990:61), character is important in fictional work because a character helps to develop the plot. Character in influenced by events just as events are shaped the plot by character.

Based on the three definitions of character which have been stated previously, it can be synthesized that character is like people in real life who have mental, emotional and social qualities, it is important in fictional work for developing the plot.

\section{a. Kinds of character}

According to kirzner character divided into two parts, there are:

\section{1) Main character}

The main character in a story is generally known as protagonist, the character who opposes him is the antagonist. Character is revealed by how a character responds to conflict. The main character who appears the most in the story and always has connection with other actors in generally there are main 
character which consist of protagonist and antagonist. The further ideas about protagonist and antagonist are presented as follows:

According to Blair (1990:10), she says that protagonist is a character that sometimes figure with positiveside but in case a villain can be also included protagonist.

Furthermore Akun (2000:30) also says that protagonist characters have a great part or role in a movie and also involve order characters to take part in a story. It means in society nature of fate as well as another person. The chief character in a play or story, who may also be opposed by antagonist originally.

Guerin (1986:76) says that antagonist is the character with who the protagonist is in conflict, generally not a sympathetic character.

The writer concludes from the statements above that the protagonist character is the opposite of the antagonist character and can make the story of movie become more interesting.

\section{2) Minor character}

The minor character consists of stock and foil. Stock characters are minor characters in a work of fiction who do not undergo substantial change or growth in the course of a story. Also referred to as "two-dimensional characters" or flat characters." They play a supporting role to the main character, who as a rule should be round, or complex.(Terry, 1988:20)

Foil character is any character who in some way compares and contrasts with another. Playwrights create foil characters to help illuminate the personality of other characters as well as to help dramatize the meaning of the play.

The writer assumes that character are different based on the necessary, even the character can support situation more attractive. Supporting character who plays good can make the movie more interesting for audience. It means the character specify based on their characteristic in the movie. Their characterization influenced the story.

\subsection{Definition of Racism}

Racism is important to talk about nowadays not because is history but because racism is still alive today. Racism has existed throughout human history. 
Long time ago in America, the racism problem is very serious and worst. The black are deserve as slave for white. The white do not care about the feeling of the black and do not regard them as human being. The white can do what they like to the black such as beaten or insulted them.

Racism may be defined as the hatred of one person by another because of skin color, language, custom, or any factor that supposedly reveals the basic nature of that person. Those have influenced slavery, wars, and the formation of nation. Racism is defined as predication of decision and policies on consideration of race for the purpose of subordinating a racial group and maintaining control over that group. Racism can more narrowly refer to a system of oppression, such as institutional racism, that is based on the idea of one race's superiority over other races (Henry, 2002: 253-283).

Hannaford (1996:215) assist that racism is a general term used to describe: "a belief or doctrine that inherent differences among the various human races determine cultural or individual achievement, usually involving the idea that one's own race is superior and has the right to rule others.

Racism is not just word but action. Mostly, the conflict about racism such as discrimination.In addition, Jones (1997:117) defined racismbroadly as follows: "[Racism] result from the transformation of race prejudice and/or ethnocentrism through the exercise of power against a racial group defined as inferior, by individuals and institution with the intentional support of the entire culture.

Racism can be happened because some people do discrimination and prejudice.

\section{a. Discrimination}

The word discrimination derives from the Latin language "discriminare", which means to distinguish between. Discrimination is an action that treats people unfairly because of their membership in a particular social group. Berger said that discrimination is a special act, a deliberate to exclude some individuals from something desirable because they are presumed (correctly or incorrectly) to belong in a certain group. The group that is the objects of discrimination are identified by means of religion, national origin, colour, language and social class. 


\section{b. Prejudice}

In the practice of racism, there is always a racial prejudice practice involved. Prejudice is a pre-judgment in the sense that is judgement concerning objects and persons not based on knowledge or experience. According to Franklin in his book is a judgment or opinion formed before hand or without due the examination. The most elemental manifestation of prejudice in this board meaning of the word is to be found in the personal likes and dislikes, preference, and antipathies which everyone exhibit in regard to food, clothes, and the art as well as person. (Franklin, 1995).

Feldman (1985: 160) asserts that prejudice and discrimination are negative manifestation of integrative powers instead of bringing and holding people together, prejudice and discrimination push the apart. Ironically, prejudice and discrimination imply some sort of relation. If there is no relationship people would be completely unaware of another person's or racial group's existence.

\subsection{Definition of Slave}

Persons defined as slaves were part of a distinct social group whose lives were routinely controlled by others. Such people in general performed arduous labour, particularly in agriculture, construction and mining, but also in households and the military, only a fortunate few working as managers, political administrators, or skilled artisans (McDonald, 2002:21).

Slavery was popular in America during 1660s to 1860s. Slaves being as property but they could not own property. The slave could have no honor because he had no power and no independent social existence, hence no public worth. He had no name of his own to defend. He could only defend his master's worth and his master's name (Orlando, 1982:14).

According to Henri Wallonin Patterson Orlando's book slavery and social death, he states

"The slave was a dominated thing, an animated instrument, a body with natural movements, but without its own reason, an existence entirely absorbed in another. The proprietor of this thing, the mover of this instrument, the soul and the reason of this body, the source of this life, 
was the master. The master was everything for him: his father and his god, which is to say, his authority and his duty... thus, god, fatherland, family, existence, are all, for the slave, identified with the same being; there was nothing which made for the social person, nothing which made for the moral person, that was not the same as his personality and his individuality." (Orlando, 1982:14).

Based on above elaboration about definition of slave, it can be inferred that slave is a person who lives controlled by others and being classed as property who is forced to work for nothing because he had no power and no independent social existence without his master.

\subsection{Definition of Slavery}

Slavery was one form of exploitation. Its special characteristics include the idea that slaves are property; that they are outsiders who are alien by origin or who are denied their heritage through judicial or other sanctions; that coercion can be used at will; that their labour power is at the complete disposal of a master; that they do not have the right to their own sexuality and, by extension, to provision is made to ameliorate that status (Paul E, 2012:1).

Based on above elaboration about definition of slavery, it can be inferred that slavery refers to exploitation in which individuals are owned by others that they do not have the right to their own sexuality and their life.

\subsection{Definition of Struggle}

In this life there are many obstacles. Struggle is one of way to against the obstacles. Without obstacles life is flat and there is no good story and people would be a weak person. Struggle also has many good benefits. Such as people have to fight the problem or obstacle and make it better for story in their live, it can make people strong as before and can avoid regret in their live. If you have struggleto do something, you tryhard to do it, even though other people or things may be making it difficult for you to succeed.

Meanwhile Jones (2007:xi) said struggle we all have them; personality quirks, natural tendencies, or the result of circumstances that have shaped us and caused difficulties in life. 
While Kelly Bersch (2015) states struggle means pushing ahead no matter what. It means investing your hope and energy even in a cause that seems hopeless. Struggle is a mark of heroism, and the difference between winners and losers.Struggle does not tire: it uplifts and rejuvenate; it brings out the best in the human spirit. If you feel that life is hard, you have not faced your toughest adversity.

In line with David Kennedy (2016:9) states struggle whose outcome can be predicted need not be undertaken to be lose or won: some struggles need only be referenced to be won decisively. It takes courage, energy, and imagination to be open what has been settled for reconsideration.

From all statements above the writer can conclude that struggle means it has quirks, natural tendencies, or the result of circumstances that emphasize the gravity of investing your hope and energy even in a cause that seems hopeless, out the best in the human spirit. If you feel that life is hard, you have not faced your toughest adversity.

Based on the above theories, the movie which is going to be analyzed is "Django Unchained" by Quentin Tarantino. The reason why the writer chooses this movie is because the movie tells about the struggle of a man slave. He fights the problem with struggle.The story really describes the struggle through the main character Django in this movie like what is told and written in David Kennedy's concept, so that is why the writer chooses the struggle's theory because it is related to the main character who live as slave and do hard struggle to against injustice from whites around him.

\section{Methodology}

In writing this research the writer uses qualitative approach to analyze the data. This chapter deals with the process of collecting information and the data. In the world of research, there are two data researches to gathering and reporting information, they are qualitative research and quantitative research. The quantitative research tends to approximate phenomena from a larger number of individuals using survey methods and the qualitative research is focused on understanding a phenomenon from a closer perspective (Cohen, 2007:461). 


\section{B. FINDING AND DISCUSSION}

\section{Kinds of struggle from the slaves through the main character reflected in the movie.}

From this movie the writer sees kinds of struggle. The struggle will be dominant that appears in main character because he lives as slave. Most of player in this movie are slaves, so that freedom is important thing for them. All of slaves live in hard pressure even until die.

Django is main character and he belongs to protagonist character. He is dynamic character because from the start to finish in the movie he changes the character. The first he is good man but in the middle of story when he meets Calvin Candie he changes the character becomes rude man. The struggle shows in Django's character when the movie starts until finish. He will do whatever the trouble as long as good for his life. The first struggle appears when he wants to find The Brittle Brother's mission with Dr Schultz, he takes a big risk. He pretends to be a freeman in front of people who meets him. Another risk when he wants to save his wife from Calvin Candie. He is brave to meet cruel Candie even he shoots him with a gun.

Django is a blessed slave who meets Dr Schultz that wants to make him being freedom. The first time he has to find the family of brittle brother, someone asks him to kill them if they do that they will get much money. He meets Dr Schultz and he agrees to join in the mission whereas it is dangerous mission for slave. He follows the mission until finish but it is not over he has another mission that is findings his wife and wants to save her from Candie. He collects information about his wife and makes it success to save her.He really loves his wife, since they are separated by master he really miss his wife. Even though he does not know where she is, but he tries to find her. He never gives up to finding his love.

Every slave needs struggle to defend their life. Like Django, he never gives up to reach his obsession even though many troubles that has to face in his life. Freedom is one of his dreams as slave.Django really wants his freedom of his live as human not a slave, because become a slave it is really hurt. Being a slave is a worst thing, because he will get punishment, torture or violence from his master, the punishment is not only violence but also about physic like he sees his wife punch by 
her master in front of him, but he cannot do anything as his wife. It makes him guilty to his wife. In the part of Django will save his wife it becomes tense part, because Django has strong struggle to make save his wife. Many troubles that must be faced for him but it does not matter, Django will not stop to save his wife.

\section{Factor that influenced the black people become slaves in the movie}

The factor that makes black people being a slave is because of history. Slavery in America began when the first African slaves were brought to the North American colony of Jamestown. Virginia. Slavery was practiced throughout the American colonies in the $17^{\text {th }}$ and $18^{\text {th }}$ and African-American slaves helped out build the economic foundations of the new nation (A\&E Television Network, LLC).

Another statement from Norman Coombs (1972:13), he says that neither slavery nor the slave trade came to West Africa with the arrival of Portuguese in the middle of the fifteenth century. Some slaves were taken by force.

It is related to this movie. Quentin Tarantino wants to tell to the audience about story of America people were treated inhumanely by White American. He makes this story similar to the fact at that time, from the setting and the background.

The Black People in the United State is considered as a low class citizen. It is proven by the history that Black People were always segregated and discriminated in dominant white society. However, Black People had been struggling for their prestige to place themselves equal to White People. They attempt to get higher level in all aspects of live.

\section{The way slaves survive in this movie}

In this case the writer tries to analyze by watching movie in many times to make understand well. It is not easy for the writer to find out the answer. One of the way slaves can survive from this movie by following their master's command, rules whatever it is. They surrender to their master even make themselves are sacrifice. If they do one mistake even little mistake their master will gives punishment without compassion. Being a slave just follows what their master's command. There is no choice for them to do objection for their master's rule.

\section{CONCLUSION}


After analyzing the struggle through the main character in movie Django Unchained, now the writer comes to the conclusion. Through this research, there are three conclusions that found from this movie. First, the writer sees the kinds of struggle from this movie, those are struggle for freedom for Django and his wife, and to get rights. All of slaves live in hard pressure even until die. It tells about how difficult to get freedom for black people as slave in that era. How hard to make same status with white people because from facilities and clothes are limited by white people.

Second, the writer finds factors that influences Black become slaves The reason it is because of history. Black Americans or before 1970 African American are descendants of enslaved Africans brought to America from 1565 through 1807 during the trans-Atlantic slave trade.

Third, the writer finds the way slaves survive from white in movie All of slaves try to defend in their live. They obey what their master's command although they will die Django can make this story happy endingwith his struggle and passion never useless for his life because finally he is together with his wife in the end of story.

\section{BIBLIOGRAPHY}

Akun. 2000. English Literature. Jakarta: Bina Nusantara University.

Blair, Elisabeth. 1990. Literature In Our Life. Bristol: Hounds Mills Mcmilan.

Cohen, Louis. 2007. Research Methods in Education, sixth edition. New York: Routledge.

Coombs, Norman. 1972. The Black Experience in America.Twayne.

E, Paul Lovejoy. 2012. Transformation in Slavery: A history of Slavery in Africa. Cambridge University Press.

Guerin. 1986. Literature and Interpretive Techniques. New York: Harper Collins Publisher.

Hannaford, Ivan. 1996. Race: the history of an idea in the west. Washington, Dc: Woodrow Wilson Center Press. 
Henry, P J., et. al. 2002. The Symbolic Racism 2000 Scale Political Psychology

Jones, D J. 2007. My Struggle, Your Struggle Breaking Free From Habitual Sin. United States of America: Xulon Press.

Jones, J M. 1997. Prejudice and racism ( $2^{\text {nd }}$ ed). New York, NY: McGraw Hill.

Kennedy, David. 2016. A world of struggle how power, law,ahape,global political economi. United kingdom:pricenton university press.

Lukens, Rebecca Emerita J. 2007.A critical Handbook of Children's Literature $\left(8^{\text {th }}\right.$ ed).Oiho: University Oxford.

McDonald, Beckles Hillary. 2002. Slave Voyage TheTranslantic Trade in Enslaved Africans. University of the West Indies.

Meyer, Michael. 1990. The Bedford Introduction to Literature. Boston: Bedford Books of St, Martin's press.

Orlando, Patterson.1982. Slavery and Social Death.USA: President and Fellows of Harvard College.

Rush, David. 2005. A student Guide to Play Analysis. Carbonale: Southern Illinois University Press.

Terry, Hudgson. 1988. Dictionary Of drama. London: Batsford Ltd.

\section{Internet}

A\&E Television Network.History in America.Retrievied April 26,2017. From http://www.history.com.

Bersch, Kelly. 2015, March 22. Struggle is The Purpose of Life. Retrievied March 6,2017, from http://www.qsl.net/ac7ew/struggle.html 